\title{
Perbandingan Efektivitas Larvasida Ekstrak Kulit dan Daging Buah Sawo (Manilkara zapota) terhadap Kematian Nyamuk Aedes aegypti
}

\author{
Comparison of Larvacide Effectiveness of Peel and Pulp Manilkara zapota Fruit on Mortality of \\ Aedes aegypti Mosquito
}

\author{
Ade Trisnawati ${ }^{1 *}$, Ardiani Samti Nur Azizah ${ }^{2)}$ \\ ${ }^{1)}$ Universitas PGRI Madiun, Teknik Kimia \\ ${ }^{2)}$ Universitas Islam Kadiri, Peternakan \\ *email: adetrisnawati14@gmail.com
}

Received: 02/12/19; Revised: 28/12/19; Accepted: 28/12/19

\begin{abstract}
Abstrak
Demam berdarah merupakan salah satu permasalahan kesehatan masyarakat yang penyebarannya dilakukan oleh nyamuk Aedes aegypti. Upaya pemberantasan nyamuk Aedes aegypti khususnya pada fase larva dapat dilakukan dengan menggunakan larvasida yang berasal dari bahan alam. Salah satu bahan alam yang berpotensi sebagai larvasida adalah buah sawo. Kulit dan daging buah sawo muda diketahui memiliki kandungan senyawa bioaktif yaitu tanin, flavonoid, dan alkaloid. Tujuan penelitian ini adalah untuk mengetahui perbandingan efektivitas larvasida pada ekstrak kulit dengan ekstrak daging buah sawo muda terhadap kematian larva Aedes aegypti. Desain penelitian yang digunakan adalah eksperimental. Konsentrasi ekstrak yang digunakan yaitu $0 \mathrm{ppm}$ (kontrol negatif), $2500 \mathrm{pp}$, 5000 ppm, 7500 ppm, 10000 ppm, 12500 ppm, 15000 ppm dan 20000 ppm. Sampel yang digunakan yaitu larva Aedes aegypti instar III sebanyak 10 larva dan diamati selama 24 jam dengan tiga kali pengulangan. Uji yang digunakan yaitu uji regresi dan uji perbedaan. Hasil uji regresi menunjukkan bahwa pengaruh pemberian ekstrak kulit buah sawo $(54,7 \%)$ lebih rendah dari ekstrak daging buah sawo $(64,3 \%)$ dalam membunuh larva uji. Hasil uji perbedaan pada konsentrasi selain 7500 ppm didapatkan nilai $\mathrm{p}<0,05$ hal ini menandakan terdapat perbedaan rata-rata kematian pada kelompok ekstrak kulit dan daging buah sawo.
\end{abstract}

Kata kunci: Aedes aegypti, Daging Buah, Kulit buah, Larvasida, Manilkara zapota

\begin{abstract}
Dengue fever is one of the public health problems that is spread Aedes aegypti. Efforts to eradicate larvae especially in the larval phase can be carried out using larvacides derived from natural materials. One of the natural ingredients that has the potential as larvacides is sapodilla fruit (Manilkara zapota). The peel and pulp of sapodilla fruit are known to contain bioactive compounds, namely tannins, flavonoids, and alkaloids. The purpose of this study was to determine comparison of larvacide effectiveness of peel and pulp Manilkara zapota fruit. The study designed was experimental. Concentration used was of 0 ppm, 2500 pp, 5000 ppm, 7500 ppm, 10000 ppm, 12500 ppm, 15000 ppm dan 20000 ppm. Samples were 10 Aedes aegypti larvae instar III and tested larvae were observed for 24 hours with three times repetition. Regression test results showed that the effect of pulp of sapodilla fruit extract (54.7\%) was lower than peel of sapodilla fruit extract (64.3\%) in killing test larvae. Test results for differences in concentrations other than 7500 ppm obtained p values $<0.05$, this indicates that there were differences in the average mortality in the group of skin extract and sapodilla fruit.
\end{abstract}

Keywords: Aedes aegypti, Larvacide, Manilkara zapota, Peel of Unripe, Pulp of Unripe 


\section{PENDAHULUAN}

Demam Berdarah Dengue (DBD) adalah penyakit yang disebabkan oleh virus dengue dan ditularkan oleh nyamuk Aedes aegypti sebagai vektor utama. Kriteria klinis infeksi virus dengue menurut World Health Organization (WHO) adalah panas tinggi mendadak, manifesti perdarahan, tes Rumple Leede positif dan hepatomegali (WHO, 2009).

Berdasarkan data dari Dinas

Kesehatan Ponorogo Jawa Timur menyatakan bahwa memasuki bulan Mei di tahun 2018 setidaknya sudah ada 187 orang yang menderita DBD. Angka tersebut dikatakan kritis dikarenakan pada tahun 2017 dalam kurun waktu setahun hanya 291 penderita dengan 2 korban meninggal dunia. Kabid Pengendalian Penyakit dan Penyehatan Lingkungan (P2PL) Dinas Kesehatan Kabupaten Ponorogo, dr. Yayuk Dwi Wahyuni, menuturkan adanya peningkatan kasus penderita demam berdarah salah satunya disebabkan oleh kurangnya kesadaran masyarakat untuk membersihkan lingkungan. Usaha untuk membasmi nyamuk Aedes aegypti telah dilakukan oleh Dinkes diantaranya dengan melakukan fogging pada lokasi yang rawan dan penyuluhan kepada masyarakat untuk menerapkan hidup sehat agar tidak terjangkit penyakit DB.

Pencarian metode-metode baru untuk membasmi sumber penularan penyakit demam berdarah sangat penting dan mendesak. Alternatif pendekatan kontrol nyamuk adalah dengan menggunakan bahan insektisida alami yang bahan dasarnya berasal dari tumbuhan yang mengandung bahan kimia (bioaktif) yang toksik terhadap serangga tetapi mudah terurai (biodegradable) di alam sehingga tidak mencemari lingkungan dan relatif aman bagi manusia (Banerjee $d k k ., 2011$ ). Selain itu, pemilihan bahan yang akan digunakan sebagai larvasida harus aman terhadap manusia ataupun organisme lain, mudah diperoleh dan diharapkan dapat memberi dampak positif pada kesehatan manusia (Pratiwi, 2013).

Salah satu jenis tanaman di Indonesia yang berpotensi dalam membunuh nyamuk adalah tanaman sawo. Tanaman ini banyak ditemukan di seluruh Indonesia karena dapat tumbuh dengan cukup baik pada berbagai suhu, curah hujan serta cukup toleran terhadap gangguan angin dan kekeringan. Getah dari buah sawo yang masih muda sering digunakan masyarakat untuk mengatasi diare. Khasiatnya sebagai antidiare ini diduga karena adanya kandungan tanin dalam jumlah yang cukup besar pada buah sawo yang masih muda (Ma $d k k ., 2003$ ). Selain itu, pada kulit buah sawo diketahui memiliki kandungan senyawa tanin (Shafii $d k k$., 2017), fenol dan flavonoid (Gomathy $d k k$., 2013) serta alkaloid (Sihombing $d k k$., 2015). Pada beberapa penelitian yang telah dilakukan menunjukkan bahwa komponen fitokimia yaitu flavonoid, alkaloid dan tanin memiliki cara kerja sebagai racun perut dan menghambat kerja enzim kolinestrase pada larva, flavonoid berperan sebagai racun pernapasan dan polifenol berperan sebagai racun perut (stomach poisoning) sehingga menyebabkan kematian larva.

Berdasarkan sifat toksik dari komponen senyawa tersebut, kulit dan buah sawo muda memiliki potensi sebagai larvasida nyamuk Aedes aegypti, tetapi belum banyak penelitian yang menggunakannya, oleh sebab itu penelitian dalam pemanfaatan kulit dan buah sawo muda sebagai larvasida perlu dilakukan. 
Perbandingan Efektivitas Larvasida Ekstrak Kulit dan Daging Buah Sawo (Manilkara zapota) terhadap Kematian Nyamuk Aedes aegypti

Tujuan penelitian ini adalah untuk mengetahui perbedaan aktivitas larvasida pada ekstrak kulit buah sawo muda jika dibandingkan dengan ekstrak daging buah sawo terhadap kematian larva nyamuk Aedes aegypti.

\section{METODE PENELITIAN}

Penelitian ini menggunakan metode eksperimen yang dilaksanakan di laboratorium. Subjek yang digunakan adalah larva nyamuk Aedes aegypti instar III. Larva nyamuk diperoleh dari Laboratorium ITD Universitas Airlangga. Selanjutnya penulisan Aedes aegypti disingkat menjadi Ae.aegypti Bahan yang digunakan dalam penelitian ini adalah kulit buah sawo muda dan daging buah sawo muda yang diperoleh dari Desa Bareng Kecamatan Babadan Kabupaten Ponorogo.

Sampel yang akan digunakan dalam penelitian ini adalah kulit buah sawo muda dan daging buah sawo muda. Buah sawo muda yang akan digunakan dicuci bersih. Kulit dan daging buah dipisahkan kemudian dikeringkan. Kedua sampel ini dihaluskan dengan blender hingga terbentuk serbuk. Masing-masing serbuk diambil sebanyak 50 gram untuk diekstraksi.

Serbuk kulit buah sawo muda dan daging buah sawo muda masing-masing sebanyak 50 gram dimaserasi dengan 250 $\mathrm{mL}$ pelarut etanol selama 24 jam pada suhu ruang dalam wadah tertutup dan terhindar dari cahaya langsung. Kemudian disaring sehingga didapatkan filtrat dan endapan. Endapan tersebut kemudian dimaserasi kembali dengan $250 \mathrm{~mL}$ etanol selama 24 jam. Semua filtrat hasil maserasi dikumpulkan dan didestilasi sehingga diperoleh ekstrak kulit buah sawo muda dan ekstrak daging buah sawo muda.
Uji larvasida dilakukan dengan menggunakan larva instar III yang dibagi dalam 2 kelompok yang diberi perlakuan dengan ekstrak kulit buah sawo muda dan ekstrak daging buah sawo muda. Sebelum melakukan uji sebenarnya, peneliti melakukan uji pendahuluan dengan konsentrasi 10000 ppm, 12500 ppm, 15000 ppm, 20000 ppm. Dari uji pendahuluan diperoleh konsentrasi yang akan digunakan pada uji sebenarnya, yaitu 0 ppm (kontrol negatif), 2500 ppm, 5000 ppm, 7500 ppm, 10000 ppm, 12500 ppm, 15000 ppm, 20000 ppm. Masing-masing kelompok berisikan 10 ekor larva. Larva diamati selama 24 jam, apabila setelah 24 jam 50 \% larva uji belum mati, maka menambah waktu pengamatan sampai 48 jam dan seterusnya sampai maksimal 96 jam karena jika lebih dari 96 jam kematian larva dapat disebabkan faktor lain. Percobaan dilakukan pengulangan sebanyak 3 kali. Data yang diperoleh akan diolah menggunakan perangkat lunak pengelola data statistik.

Data dianalisis dengan uji normalitas data, uji regresi dan uji perbedaan. Uji normalitas dianalisis dengan uji SaphiroWilk untuk mengetahui apakah data terdistribusi normal atau tidak. Uji regresi linier digunakan untuk mengetahui pengaruh dari tiap konsentrasi ekstrak terhadap jumlah kematian larva nyamuk Ae.aegypti. Nilai $\mathrm{R}$ dapat menunjukkan tingkat hubungan antar variabel bebas (konsentrasi ekstrak) dengan variabel terikat (jumlah kematian larva nyamuk Ae.aegypti), nilai $\mathrm{R}^{2}$ menunjukkan pengaruh perlakuan. Uji perbedaan digunakan untuk mengetahui apakah ada perbedaan efektivitas ekstrak kulit buah sawo muda dan daging buah sawo terhadap kematian larva Ae.aegypti . 
Perbandingan Efektivitas Larvasida Ekstrak Kulit dan Daging Buah Sawo (Manilkara zapota) terhadap Kematian Nyamuk Aedes aegypti

\section{HASIL DAN PEMBAHASAN}

Insektisida hayati misalnya larvasida pada penelitian ini menggunakan bahan dasar kulit dan daging buah sawo muda yang diekstrak dengan etanol. Serangga yang digunakan adalah larva Ae.aegypti yang merupakan vektor penyakit demam berdarah.

Pemilihan instar larva menjadi bagian yang penting karena larva tersebut menjadi obyek dalam penelitian ini. Jika salah memilih instar larva maka akan mengakibatkan tingkat kematian larva yang terlalu cepat sehingga tidak sesuai dengan tujuan penelitian. Penelitian ini menggunakan larva instar III karena larva instar III mempunyai pertumbuhan dan perkembangan yang lebih tinggi dari larva instar II. Berbagai konsentrasi dari ekstrak kulit buah sawo muda dan daging buah sawo muda diberikan pada larva Ae.aegypti instar III. Kedua ekstrak ini memberikan hasil yang berbeda terhadap kematian larva nyamuk Ae.aegypti dalam pengamatan 24 jam. Berdasarkan penelitian yang telah dilakukan, didapatkan data berupa jumlah kematian larva Ae.aegypti pada beberapa konsentrasi larutan ekstrak dan pengulangan seperti yang terlihat pada Tabel 1 dan Tabel 2.

Tabel 1. Jumlah Kematian Larva Ae.aegypti setelah 24 jam pada Pemberian Ekstrak Kulit Buah Sawo Muda

\begin{tabular}{|c|c|c|c|c|c|c|c|c|}
\hline \multirow{2}{*}{$\begin{array}{l}\text { Perlakuan } \\
\text { Ke- }\end{array}$} & \multicolumn{8}{|c|}{ Konsentrasi Ekstrak Kulit Buah Sawo Muda (ppm) } \\
\hline & 0 & 2500 & 5000 & 7500 & 10000 & 12500 & 15000 & 20000 \\
\hline I & 0 & 1 & 1 & 3 & 3 & 4 & 5 & 5 \\
\hline II & 0 & 0 & 1 & 2 & 2 & 5 & 4 & 4 \\
\hline III & 0 & 1 & 0 & 2 & 3 & 4 & 4 & 5 \\
\hline $\begin{array}{l}\text { Total } \\
\text { Larva }\end{array}$ & 0 & 2 & 2 & 7 & 8 & 13 & 13 & 14 \\
\hline $\begin{array}{l}\text { Rata-rata } \\
\text { Larva }\end{array}$ & 0 & 0,67 & 0,67 & 2,33 & 2,67 & 4,33 & 4,33 & 4,67 \\
\hline
\end{tabular}

Tabel 2. Jumlah Kematian Larva Ae.aegypti setelah 24 jam pada Pemberian Ekstrak Daging Buah Sawo Muda

\begin{tabular}{lcccccccc}
\hline Perlakuan & \multicolumn{7}{c}{ Konsentrasi Ekstrak Daging Buah Sawo Muda (ppm) } \\
\cline { 2 - 10 } \multicolumn{1}{c}{ Ke- } & 0 & 2500 & 5000 & 7500 & 10000 & 12500 & 15000 & 20000 \\
\hline I & 0 & 4 & 5 & 4 & 7 & 10 & 9 & 9 \\
\hline II & 0 & 4 & 5 & 4 & 6 & 10 & 9 & 9 \\
\hline III & 0 & 3 & 4 & 3 & 6 & 9 & 8 & 9 \\
\hline $\begin{array}{l}\text { Total } \\
\text { Larva }\end{array}$ & 0 & 11 & 14 & 11 & 19 & 29 & 26 & 27 \\
\hline $\begin{array}{l}\text { Rata-rata } \\
\text { Larva }\end{array}$ & 0 & 3,67 & 4,67 & 3,67 & 6,33 & 9,67 & 8,67 & 9 \\
\hline
\end{tabular}

Berdasarkan Tabel 1 dan 2 hasil pengukuran kematian larva Ae.aegypti menunjukkan bahwa ekstrak kulit buah sawo muda dan ekstrak daging buah sawo muda memiliki kemampuan sebagai larvasida pada larva nyamuk Ae.aegypti .
Hal ini dapat dilihat dari hasil percobaan yang membuktikan pada semua kelompok uji coba yang diberikan sampel ekstrak terdapat larva yang mati. Peningkatan konsentrasi ekstrak menyebabkan penurunan aktivitas larva seperti gerakan 
Perbandingan Efektivitas Larvasida Ekstrak Kulit dan Daging Buah Sawo (Manilkara zapota) terhadap Kematian Nyamuk Aedes aegypti

naik turun ke permukaan yang sudah melambat, serta respon terhadap sentuhan yang sudah menurun hingga didapatkan kematian larva. Pemberian ekstrak daging buah sawo muda pada konsentrasi 12500 ppm, 15000 ppm dan 20000 ppm menyebabkan kematian hampir $100 \%$. Konsentrasi tersebut dinilai sangat toksik bagi larva Ae.aegypti, sedangkan pada pemberian ekstrak kulit buah sawo muda pada konsentrasi 12500 ppm, 15000 ppm dan 20000 ppm hanya menyebabkan kematian hampir $50 \%$.

Data yang diperoleh kemudian dilakukan uji regresi untuk mengetahui seberapa besar pengaruh ekstrak kulit dan daging buah sawo dalam menyebabkan kematian larva Ae.aegypti. Hasil uji analisis regresi diberikan pada Tabel 3 .

Tabel 3. Hasil Uji Regresi Rata-rata Kematian Larva Uji yang diberi Ekstrak Kulit Buah Sawo Muda dan Daging Buah Sawo Muda

\begin{tabular}{llll}
\hline Perlakuan & r & $\mathbf{R}^{2}$ & P-Value \\
\hline $\begin{array}{l}\text { Ekstrak Kulit Buah Sawo } \\
\text { Muda }\end{array}$ & 0,740 & 0,547 & 0,093 \\
\hline Ekstrak Daging Buah Sawo & 0,802 & 0,643 & 0,055 \\
\hline
\end{tabular}

Berdasarkan Tabel 3 dapat diketahui hasil analisis regresi yang masing-masing nilai memiliki makna. Hasil uji regresi pada perlakuan pemberian ekstrak kulit buah sawo muda terhadap kematian larva nyamuk diperoleh nilai $\mathrm{R}$ sebesar 0,740 , artinya korelasi variabel bebas dan variabel terikat memiliki hubungan sangat erat karena mendekati angka 1 . Nilai $\mathrm{R}^{2}$ sebesar 0,547 artinya pengaruh pemberian ekstrak kulit buah sawo dalam membunuh larva uji sebesar 54,7 \%, sisanya dipengaruhi variabel lain.

Hasil uji regresi pada perlakuan pemberian ekstrak daging buah sawo muda terhadap kematian larva nyamuk diperoleh nilai $\mathrm{R}$ sebesar 0,802 , artinya korelasi variabel bebas dan variabel terikat memiliki hubungan sangat erat karena mendekati angka 1 . Nilai $\mathrm{R}^{2}$ sebesar 0,643 artinya pengaruh pemberian ekstrak daging buah sawo dalam membunuh larva uji sebesar 64,3\%, sisanya dipengaruhi variabel lain.

Berdasarkan hasil analisis regresi terlihat bahwa pengaruh pemberian ekstrak kulit buah sawo dalam membunuh larva uji yaitu 54,7 \% lebih rendah jika dibandingkan pengaruh pemberian ekstrak daging buah sawo dalam membunuh larva uji yaitu $64,3 \%$.

Tahap uji selanjutnya adalah uji perbedaan, tetapi sebelum itu perlu dilakukan uji normalitas untuk mengetahui apakah data yang akan diuji terdistribusi normal atau tidak. Data terdistribusi normal atau tidak digunakan sebagai dasar untuk menentukan penggunaan uji perbedaan yang sesuai baik uji parametrik atau uji non-parametrik. Hasil uji normalitas ditunjukkan pada Tabel 4. 
Perbandingan Efektivitas Larvasida Ekstrak Kulit dan Daging Buah Sawo (Manilkara zapota) terhadap Kematian Nyamuk Aedes aegypti

Tabel 4. Hasil Uji Normalitas Kematian Larva Uji yang diberi Ekstrak Kulit Buah Sawo Muda dan Daging Buah Sawo Muda dengan Uji Saphiro Wilk

\begin{tabular}{|c|c|c|c|}
\hline Perlakuan & Konsentrasi & Mean $\pm S D$ & P-value \\
\hline \multirow{7}{*}{$\begin{array}{c}\text { Ekstrak Kulit Buah Sawo } \\
\text { Muda }\end{array}$} & 2500 & $0,67 \pm 0,58$ & \multirow{7}{*}{0,000} \\
\hline & 5000 & $0,67 \pm 0,57$ & \\
\hline & 7500 & $2,33 \pm 0,58$ & \\
\hline & 10000 & $2,67 \pm 0,58$ & \\
\hline & 12500 & $4,33 \pm 0,58$ & \\
\hline & 15000 & $4,33 \pm 0,58$ & \\
\hline & 20000 & $4,67 \pm 0,58$ & \\
\hline \multirow{7}{*}{$\begin{array}{l}\text { Ekstrak Daging Buah } \\
\text { Sawo Muda }\end{array}$} & 2500 & $3,67 \pm 0,57$ & \multirow{7}{*}{0,000} \\
\hline & 5000 & $4,67 \pm 0,57$ & \\
\hline & 7500 & $3,67 \pm 0,57$ & \\
\hline & 10000 & $6,33 \pm 0,57$ & \\
\hline & 12500 & $9,67 \pm 0,57$ & \\
\hline & 15000 & $8,67 \pm 0,57$ & \\
\hline & 20000 & $9.00 \pm 0.57$ & \\
\hline
\end{tabular}

Hasil uji normalitas dengan Shapirowilk baik pada kelompok ekstrak kulit buah sawo muda dan daging buah sawo muda menunjukkan bahwa data terdistribusi tidak normal $(\mathrm{p}<0,05)$.
Kemudian uji perbedaan dilakukan dengan menggunakan uji non-parametrik Mann Whitney. Hasil uji perbedaan dengan Mann Whitney ditunjukkan pada Tabel 5.

Tabel 5. Hasil Uji Mann Whitney Pengukuran Kematian Larva Ae.aegypti setelah diberikan Ekstrak Kulit Buah Sawo Muda dan Daging Buah Sawo Muda

\begin{tabular}{ccc}
\hline $\begin{array}{c}\text { Konsentrasi Ekstrak Kulit Buah Sawo Muda - Daging } \\
\text { Buah Sawo Muda }\end{array}$ & Signifikansi & Kesimpulan \\
\hline $2500 \mathrm{ppm}$ & 0,043 & Ada \\
\hline $5000 \mathrm{ppm}$ & 0,043 & Ada \\
\hline $7500 \mathrm{ppm}$ & 0,068 & Tidak ada \\
\hline $10000 \mathrm{ppm}$ & 0,043 & Ada \\
\hline $12500 \mathrm{ppm}$ & 0,043 & Ada \\
\hline $15000 \mathrm{ppm}$ & 0,043 & Ada \\
\hline $20000 \mathrm{ppm}$ & 0,034 & Ada \\
\hline
\end{tabular}

Hasil uji perbedaan Mann-Withney ekstrak kulit buah sawo muda dan daging buah sawo muda pada konsentrasi 2500 ppm, 5000 ppm, 10000 ppm, 12500 ppm, 15000 ppm dan 20000 ppm terhadap kematian larva didapatkan nilai $\mathrm{p}<0,05$ yang menandakan bahwa terdapat perbedaan yang bermakna pada masingmasing kelompok. Hasil analisis pada konsentrasi 7500 ppm menunjukkan hasil tidak ada perbedaan karena nilai $\mathrm{p}>0,05$.
Berdasarkan hasil penelitian ini diketahui bahwa ekstrak kulit buah sawo muda dan daging buah sawo muda dapat dijadikan sebagai agen larvasida. Ekstrak kulit dan daging buah sawo muda positif mengandung alkaloid, flavonoid dan tanin (Trisnawati, 2018). Alkaloid menghambat proses metabolisme pada larva, mengganggu hormon pertumbuhan, dan mencerna protein dalam tubuh larva serta mengubahnya menjadi derivatif peptone 
Perbandingan Efektivitas Larvasida Ekstrak Kulit dan Daging Buah Sawo (Manilkara zapota) terhadap Kematian Nyamuk Aedes aegypti

yang akan membuat larva sebagai kekurangan makanan dan akhirnya mati (Utomo, 2013). Musau dkk. (2016) melaporkan bahwa kandungan metabolit sekunder seperti alkaloid dan flavonoid dapat digunakan sebagai insektisida. Senyawa flavonoid telah diketahui terdeteksi pada semua bagian buah karena senyawa ini merupakan golongan senyawa polifenol alami yang dapat ditemukan pada banyak buah, sayur, biji, bunga, daun, akar dan sebagainya (Salusu $d k k$., 2017). Bila senyawa flavonoid masuk ke mulut larva dapat mengakibatkan kelemahan pada saraf dan kerusakan pada spirakel sehingga larva tidak bisa bernafas dan akhirnya mati (Yuliawati, 2017). Selain itu, flavonoid juga mempengaruhi sistem pernapasan pada serangga, flavonoid yang masuk kedalam tubuh serangga dapat melumpuhkan saraf pernapasan serangga sehingga mengakibatkan kematian (Cania \& Setyaningrum, 2013). Senyawa tanin dapat menurunkan kemampuan untuk mencerna makanan dengan menurunkan aktivitas enzim dalam mencerna makanan pada nyamuk (protease dan amilase) (Ahdiyah \& Purwani, 2015).

Ekstrak daging buah sawo muda lebih efektif daripada ekstrak kulit buah sawo muda dalam membunuh larva Ae.aegypti. Perbedaan jumlah kematian larva pada kedua ekstrak dipengaruhi oleh perbedaan jumlah bahan aktif yang terkandung. Berdasarkan penelitian yang telah dilakukan oleh Trisnawati (2018) diketahui bahwa jumlah bahan aktif dalam ekstrak daging buah sawo muda lebih banyak jika dibandingkan dalam ekstrak kulit buah sawo muda dibuktikan dengan warna ekstrak daging buah sawo muda yang lebih keruh dari ekstrak kulit buah sawo muda. Hal ini disebabkan karena buah muda sawo memiliki kandungan tanin yang tinggi yang dapat memberikan rasa sepat di mulut (Milind \& Preeti, 2015). Ma $d k k$. (2003) juga melaporkan bahwa pada buah terutama yang muda ditemukan kandungan yang banyak akan senyawa polifenol seperti tanin and flavonoid. Senyawa tanin dapat menurunkan kemampuan untuk mencerna makanan dengan menurunkan aktivitas enzim dalam mencerna makanan pada nyamuk (protease dan amilase) (Ahdiyah \& Purwani, 2015).

Dengan demikian, maka telah diketahui bahwa ekstrak kulit dan daging buah sawo muda memiliki potensi sebagai larvasida nyamuk Ae.aegypti karena adanya kandungan senyawa kimia berupa alkaloid, flavonoid dan tanin. Beberapa hasil penelitian juga menunjukkan bahwa ekstrak kulit dan daging buah pada tanaman lain juga dapat dijadikan sebagai larvasida, diantaranya adalah kulit buah pepaya, kulit buah jeruk manis dan daging buah jeruk. Kulit buah pepaya dapat dijadikan larvasida karena adanya efek dari komponen fitokimia flavonoid, alkaloid dan tanin (Hayatie $d k k$., 2015). Kulit buah jeruk manis mengandung tanin, saponin, flavonoid dan limonoid (Nurhaifah \& Sukesi, 2015). Buah jeruk diketahui mengandung alkaloid, flavonoid, saponin, fenolik dan tanin sehingga memiliki aktivitas larvasida terhadap larva Ae.aegypti (Effiom dkk., 2012).

\section{KESIMPULAN}

Dari penelitian ini didapatkan bahwa ekstrak kulit buah sawo muda dan daging buah sawo muda memiliki efek larvasida terhadap larva nyamuk Ae.aegypti. Ekstrak daging buah sawo muda lebih efektif membunuh larva nyamuk 
Perbandingan Efektivitas Larvasida Ekstrak Kulit dan Daging Buah Sawo (Manilkara zapota) terhadap Kematian Nyamuk Aedes aegypti

Ae.aegypti jika dibandingkan dengan ekstrak kulit buah sawo muda.

Saran untuk penelitian ini adalah perlu dilakukan penelitian lanjut dari kandungan zat dalam kulit dan daging buah sawo yang paling dominan berperan sebagai larvasida. Selain itu perlu dilakukan uji analisis lanjut yaitu uji probit LC50 dan LT50 agar diketahui konsentrasi ekstrak dan waktu yang dibutuhkan ekstrak untuk membunuh $50 \%$ dari total larva uji.

\section{DAFTAR RUJUKAN}

Ahdiyah, I., \& Purwani, K. I. (2015). Pengaruh Ekstrak Daun Mangkokan (Nothopanax scutellarium) sebagai Larvasida Nyamuk Culex sp., Jurnal Sains dan Seni ITS, 4(2), 32-36.

Banerjee, S., Singha, S., Laskar, S., \& Chandra, G. (2011). Efficacy of Limonia acidissima L. (Rutaceae) leaf extract on larval immatures of Culex quinquefasciatus Say 1823. Asian Pasific Journal of Tropical Medicine, (2011), 711-716.

Cania, E. \& Setyaningrum, E. (2012). Larvacide Effectiveness Test of the Legundi's Leaf (Vitex trifolia) Extract for Larvae of Ae.aegypti . Lampung: Medical Faculty of Lampung University.

Effiom, O. E., Avoaja, D. A., \& Ohaeri, C. C. (2012). Mosquito Repellent Activity of Phytochemical Extracts from Peels of Citrus Fruit Species. Global Journal of Science Frontier Research Interdiciplinary, 12(1), 5-8.

Gomathy, K., Baskar, R., \& Kumaresan, K. (2013). Comparison of antioxidant potential in pulp and peel extracts of Manilkara zapota (L.) P. Royen. African Journal of Biotechnology, 12(31), 4936-4943.
Hayatie, L., Biworo, A., \& Suhartono, E. (2015). Aqueous Extract of Seed and Peel of Carica Papaya Against Aedes aegypti. Journal of Medical and Bioengineering, 4(5), 417-421.

Ma, J., Luo, X., Protiva, P., Yang, H., Ma, C., \& Basile, M. J. (2003). Bioactive novel polyphenols from the Fruit of Manilkara zapota (Sapodilla). J Nat Prod., 66, 983-986.

Milind, P \& Preeti. 2015. Chickoo: Awonderful Gift from Nature. International Journal of Research in Ayurveda Pharmacy, 6(4), 544-550.

Musau, J. K., Mbaria, J. M., Nguta, J. M., Mathiu, J. M., \& Kiama, S. G. (2016). Phytochemical composition and larvacidal properties of plants used for mosquito control in Kwale Country, Kenya. International Journal of Mosquito Research, 3(3), 12-17.

Nurhaifah, D., \& Sukesi, T. W. (2015). Efektivitas Air Perasan Kulit Jeruk Manis sebagai Larvasida Nyamuk Aedes aegypti. Jurnal Kesehatan Masyarakat Nasional, 9(3), 207-213.

Pratiwi, A. (2013). Penerimaan Masyarakat terhadap Larvasida Alami. Jurnal Kesehatan Masyarakat, 8(1), 88-93.

Salusu, H. D., Ariani, F., Obeth, E., Rayment, M., Budiarsono, E., Kusuma, I. W., \& Arung, E. T. (2017). Phytochemical Screening and Antioxidant Activity of Selekop (Lepisanthes amoena) Fruit. AGRIVITA Journal of Agricultural Science, 39(2), 214-218.

Shafii, Z. A., Basri, M., Malek, E. A., \& Isimail, M. (2017). Phytochemical and Antioxidant Properties of Manilkara zapota (L.) P. Royen Fruit Extracts and its Formulation for 
Perbandingan Efektivitas Larvasida Ekstrak Kulit dan Daging Buah Sawo (Manilkara zapota) terhadap Kematian Nyamuk Aedes aegypti

Cosmeceutical Application. Asian Journal of Plant Science and Research, 7(3), 29-41.

Sihombing, J. R., Dharma, A., Chaidir, Z., A., Fachrial, E., \& Munaf, E. (2015). Phytochemical screening and antioxidant activities of 31 fruit peel extract from Sumatera, Indonesia. Journal of Chemical and Pharmaceutical Research, 7(11), 190-196.

Trisnawati, A. (2018). Uji Kandungan Senyawa Kimia Ekstrak Kulit Sawo atang dan Buah Sawo Muda (Manilkara zapota). Prosiding Seminar Nasional Kimia 2018 "Eksplorasi Bahan Alam sebagai Inovasi Sains untuk Kemajuan Indonesia" yang diselenggarakan oleh Departemen Kimia Fakultas Matematika dan Ilmu Pengetahuan Alam Universitas Padjadjaran, tanggal 5 Mei 2018. Jatinangor: Universitas Padjadjaran.

Utomo, M. (2013). Own power plant-bsed ingredients of papaya seed powder against dealth Aedes aegypti larvae isolates SALATIGAB2P2VRP laboratory. Proceedings of the National Seminar UNIIMUS.

World Health Organization. Dengue guidelines for diagnosis, treatment, prevention and control-new edition. 2009: 3-25.

Yuliawati, R., Kurniawan, D., \& Sari, I. P. (2017). Efektifitas Ekstrak Etanol Kelopak Buah Sonneratia alba sebagai Larvasida Aedes aegypti. Sanitasi: Jurnal Kesehatan Lingkungan, 9(2), 74-79. 